\title{
A geological model for the management of subsurface data in the urban environment of Barcelona and surrounding area
}

\author{
Enric Vázquez-Suñée ${ }^{1,2}$, Miguel Ángel Marazuela ${ }^{1,2,3}$, Violeta Velasco ${ }^{1,2}$, Marc Diviu $^{1,2}$, Andrés Pérez-Estaún ${ }^{4}$, and \\ Joaquina Álvarez-Marrón ${ }^{4}$ \\ ${ }^{1}$ Institute of Environmental Assessment and Water Research IDÆA - CSIC, Jordi Girona 18, 08034 Barcelona, Spain \\ ${ }^{2}$ Associated Unit: Hydrogeology Group (UPC-CSIC) \\ ${ }^{3}$ Department of Geotechnical Engineering and Geosciences, Universitat Politècnica de Catalunya (UPC), Jordi Girona 1-3, \\ 08034 Barcelona, Spain \\ ${ }^{4}$ Institute of Earth Sciences Jaume Almera ICTJA - CSIC, Lluís Solé Sabarís s/n, 08028 Barcelona, Spain \\ Correspondence to: Enric Vázquez-Suñé (enric.vazquez@idaea.csic.es)
}

Received: 7 April 2016 - Published in Solid Earth Discuss.: 15 April 2016

Revised: 29 July 2016 - Accepted: 1 August 2016 - Published: 16 September 2016

\begin{abstract}
The overdevelopment of cities since the industrial revolution has shown the need to incorporate a sound geological knowledge in the management of required subsurface infrastructures and in the assessment of increasingly needed groundwater resources. Additionally, the scarcity of outcrops and the technical difficulty to conduct underground exploration in urban areas highlights the importance of implementing efficient management plans that deal with the legacy of heterogeneous subsurface information. To deal with these difficulties, a methodology has been proposed to integrate all the available spatio-temporal data into a comprehensive spatial database and a set of tools that facilitates the analysis and processing of the existing and newly added data for the city of Barcelona (NE Spain). Here we present the resulting actual subsurface 3-D geological model that incorporates and articulates all the information stored in the database. The methodology applied to Barcelona benefited from a good collaboration between administrative bodies and researchers that enabled the realization of a comprehensive geological database despite logistic difficulties. Currently, the public administration and also private sectors both benefit from the geological understanding acquired in the city of Barcelona, for example, when preparing the hydrogeological models used in groundwater assessment plans. The methodology further facilitates the continuous incorporation of new data in the implementation and sustainable management of urban groundwater, and also contributes to significantly reducing the costs of new infrastructures.
\end{abstract}

\section{Introduction}

The need for a groundwater supply has led people to settle near natural water sources since ancient times, usually near major rivers. For this reason, many of the world's major cities are located above alluvial or deltaic aquifers (Carlson et al., 2011; Davies, 2015; Gleeson et al., 2015; Tessler et al., 2015). Currently, particularly with the industrialization that began in the 1950s, most of these aquifers have been severely affected in terms of the quantity and quality of their waters (Aeschbach-Hertig and Gleeson, 2012; Gleeson et al., 2012b).

Urban expansion generates an enormous demand for infrastructure and, paradoxically, progressively less space for construction (Grimm et al., 2008). As a result, cities must grow downward, which requires subterranean construction (e.g. transportation networks and underground parking garages). These subterranean infrastructures usually interact with shallow aquifers, causing frequently negative repercussions for them (Attard et al., 2015; Ferguson, 2004; Ferguson and Woodbury, 2007; Kazemi, 2011; McDonald et al., 2014; Menberg et al., 2013; Taniguchi et al., 2008; VázquezSuñé et al., 2005; Vörösmarty et al., 2000). Various contamination pathways associated with this problem include spillways, sewage networks, and discharges into wells. Another result of urbanization is an abundance of hardscapes, which severely reduce the amount of aquifer recharge (VázquezSuñé et al., 2010). 
The European Water Framework Directive was developed in response to these problems faced by society in the twentyfirst century (WFD, 2000). Its objective was to unify water management in the European Union by defining long-term needs and actions to be performed in various countries. It is an important step in the management and assessment of groundwater in general. However, its regulations are typically too lax and do not provide for adequate management of urban aquifers required for the sustainable, controlled exploitation of water and geothermal resources (Epting et al., 2013; García-Gil et al., 2015b; Gleeson et al., 2012a; Vázquez-Suñé et al., 2006).

The literature contains several solutions and ideas for general groundwater management or for assessment of specific problems related to subsurface constructions in urban areas (García-Gil et al., 2015c; Parriaux et al., 2004; Zhou et al., 2015). Almost all of these studies conclude that numerical models of current and future aquifer conditions are the primary tool for accomplishing this objective. The development of comprehensive numerical models requires detailed geological models that represent the heterogeneity of the media in three dimensions.

In the absence of an extensive geological knowledge of the subsurface, which is also crucial for construction planning and for security reasons (Huggenberger et al., 2013; Santanach et al., 2011; Velasco et al., 2012a), the geological model as a basis for the hydrogeological models will be incomplete or will fail.

A sound geological analysis can be performed only if sufficient data are available. However, geological features are increasingly difficult to observe due to growing urbanization (Huggenberger and Epting, 2011), and the difficulty of performing geological and geophysical exploration in dense urban areas leads to a need for specific exploratory techniques.

In cities, it is very important to compile existing historical information. Although a large amount of information is typically available (Culshaw and Price, 2011), much of this information is not stored in standardized or ordered formats but rather is dispersed among the various companies and public institutions that generated them using different protocols and criteria. Close collaboration is needed between an administration supplying the data and a research team investigating the geology (de Rienzo et al., 2008; Di Salvo et al., 2012). New methods of managing geological data in urban areas are necessary: without these, it is much more complex and difficult to develop management plans for aquifers and subterranean construction in densely populated environments.

Apart from a detailed geological model, a reliable hydrogeological model must use other information available such as data from hydrometeorology, geography, hydrochemistry, etc. The data from each field complement the interpretation of data from the rest of the fields. For example, a reliable geological analysis enables us to perform a proper parameterization of the study area that can be complemented with an aquifer test, or a detailed hydrochemical analysis allows us to re-interpret the geology (Velasco, 2013).

The aim of this study is twofold: first we present a methodology for integrating all the required data (e.g. geological, hydrogeological, and geophysical data). The data that are from different sources (e.g. public administration or private companies) and presented in a different format are converted into a standardized, accessible database using effective datamanagement tools. These instruments facilitate the analysis, interpretation, and pre- and post-processing of the data that are later used for modelling. Secondly, we show how this challenge was met in the city of Barcelona, i.e. how the geology was modelled, and consequently how a better management of the aquifer was achieved. It should be highlighted that the workflow presented can be applied to other study areas.

\section{Regional setting}

The study area is located along the northeastern coast of the Iberian Peninsula and includes much of the cities of Barcelona, Sant Adrià, Badalona, and Santa Coloma de Gramenet (Spain) (Fig. 1). It is bounded on the west and northwest by the Collserola and Marina ranges, and on the east and southeast by the Mediterranean Sea.

The topography of the municipalities of Barcelona can be divided into three geomorphic areas. First, the Collserola and Marina ranges trend NE-SW parallel to the coast and consist primarily of Paleozoic granitic and metamorphic rocks. Second, Paleogene and Neogene rocks are exposed in a band parallel to these ranges and along a fault; these rocks are mostly covered by alluvial deposits eroded from the steep adjacent slopes. Third, underlying gently sloping plains extending to the coast there are Quaternary detrital materials associated with the deltas of the Llobregat and Besòs rivers and the coastal plain of Badalona. Most of the study area, particularly the low-lying portion, has been strongly modified by anthropic activity, and many exposures of the geology have been covered or destroyed. Most of the studied area is located on the littoral plain of the Catalan Coastal Range and the Besòs River delta.

The Catalan Coastal Range is the western onshore margin of the Valencia trough, which has a NE-SW orientation controlled by a set of faults that dip SE and have experienced repeated offsets throughout their history. This fault system is $200 \mathrm{~km}$ wide and $400 \mathrm{~km}$ long (Banda and Santanach, 1992). These extensional faults have been active since the late Oligocene, primarily during the Miocene, and are still active today (Roca and Guimerà, 1992).

The geometry and depositional characteristics of the Paleogene and Neogene deposits display evidence of two major episodes of deformation. The first episode was one of compressive intraplate tectonics associated with the Alpine orogeny and was recorded in lower Oligocene deposits in 


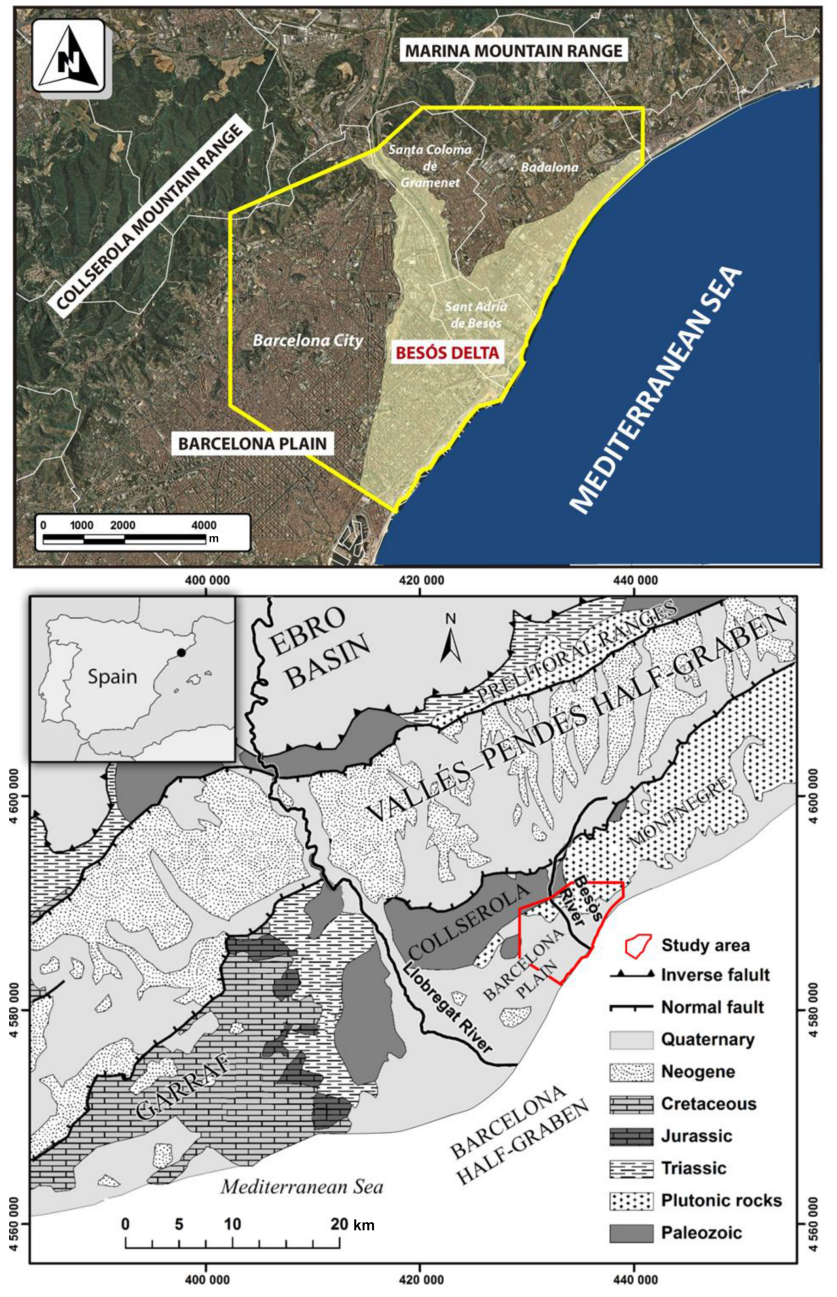

Figure 1. Top: orthophotograph of the northeastern Mediterranean coast of Spain covering the extent of the Barcelona study area (IGN PNOA). Note the intense urbanization of this region, hindering outcrop existence. Bottom: geological setting of Barcelona and surroundings. Coordinates are in Universal Transverse Mercator (UTM), zone 31 .

an offshore piggyback basin. Simultaneously, the foreland basin of the Pyrenees (Ebro Basin) subsided. The second episode was extensional and included syn-rift and post-rift stages. The syn-rift stage was recorded in upper Oligocene and lower Miocene deposits that filled a graben created during this period. The post-rift stage began in the late Langhian and extends to the present. It is characterized by an attenuation of tectonic activity and significant deposition that covered the horsts developed in the previous episode (Roca et al., 1999; Salvany, 2013). Syntectonic erosion of rocks affected by compressive structures generated during the $\mathrm{Pa}$ leogene and Neogene exhumation associated with the extensional phase altered the amplitudes and ratios of vertical movements (Gaspar-Escribano et al., 2004; Lewis et al., 2000). This erosion exposed Variscan metamorphic and in- trusive rocks in the littoral and pre-littoral chains (Solé et al., 2002). The plain of Barcelona is underlain primarily by alluvial deposits eroded from the Collserola range. Its northeastern portion is underlain by Holocene deposits of the Besòs River.

\section{Materials and methods}

This study of the geology of Barcelona reflected the particular local urban characteristics. The approach involved collecting historical data and acquiring new data.

\subsection{Previous data and historical studies}

Collecting historical data in an urban environment is important; yet its use is complex due to the difficulty of testing its quality and the inability to observe exposures destroyed in recent decades by heavy urbanization. Of all the material consulted, technical reports prepared during the twentieth and early twenty-first centuries stand out due to the large amount of subsurface information they contain. In some cases, these reports contain the only records of ancient exposures.

Certain researchers (e.g. Llobet-Vall-llosera, 1840) performed morphological and hydrogeological studies of the city of Barcelona, which included the network of important streams in Barcelona. They also noted the major lithologic characteristics of the materials underlying the region based on findings from 34 wells. In 1891, a topographical and hydrogeological study of the city provided a list of 27 wells with lithologic descriptions (García-Faria, 1891). Almera (1894) studied the Pliocene materials. The first study of the Besòs River delta was performed in the late nineteenth century and yielded the first data regarding its composition (Moracas, 1896). In 1900, the Council of Barcelona published the first geological map of Barcelona at a scale of $1: 40000$. These studies provide an understanding of the original stream network, much of which has been channelized and diverted.

At the beginning of the twentieth century with the study by Rubio and Kindelan (1909), which was based on data from numerous wells (some as deep as $173 \mathrm{~m}$ ), there was a substantial improvement in the understanding of the subsurface below Barcelona. The map of Barcelona based on the American flight of 1956 at $1: 50000$ scale is highly useful for mapping ancient geological exposures. In the middle of the twentieth century, the first study of the Quaternary deposits was performed (Solé-Sabarís, 1963).

Geological mapping from the second series of the Spanish Geological Survey mapping plan at a 1:50000 scale was used (IGME, 1977). This work was later integrated with the current Institut Cartogràfic i Geològic de Catalunya (IGCIGME, 2005) and with the $1: 25000$ scale geological map by Ventayol et al. (1978), Ventayol (2016). Sanz Parera (1988) compiled and synthesized geological and hydrogeological 
information regarding the Barcelona Plain; this information was updated by Riba and Colombo (2009).

\subsection{New data acquisition and methodology}

The absence of outcrops and the difficulty of applying certain techniques often used in geological exploration have meant adapting these techniques or, in many cases, developing new techniques to achieve the objectives.

During the previous 20 years, the Hydrogeology Group (CSIC-UPC) has performed extensive hydrogeological research in the vicinity of Barcelona, prompted mostly by the local governments of Barcelona, Santa Coloma, and Badalona, etc. These studies focused on the management of groundwater resources and on the hydrogeological aspects of excavations, tunnels (e.g. the Metro and high-speed train), drainages, and other infrastructures. These studies generated a large amount of geological and hydrogeological information that improved our knowledge of the subsurface below Barcelona.

The major source of information for this study consisted of exploratory surveys. First, a review of all existing surveys was performed, and all that were relevant were reinterpreted. Second, newer surveys that were part of various projects in which the research group was involved were incorporated. This review included a total of 714 surveys currently available in the study area, and a total of 1462 surveys including those from the immediate vicinity. Furthermore, additional observations consisted of detailed studies of the limited outcrops available in the city parks and the road cuts as well as geological interpretation of old aerial photographs (taken in the 1950s just before urban sprawl affected the area).

All the information from construction projects, surveys, and nearby exposures together with geophysical profiles (Martí et al., 2008; Gámez et al., 2009; Velasco, 2013; Velasco et al., 2012a and b) were standardized and entered into the geodatabase for modelling and analysis in a geographic information system (GIS) environment, concretely, in ArcGIS (ESRI). This geospatial database is part of a complete ongoing software platform that arranges all the available data into a coherent structure and provides support for their proper management, analysis, and interpretation. The GIS-based tools mainly provide three families of utilities aimed at facilitating.

a. Geological analysis and 3-D modelling is facilitated using the set of tools HEROS and HEROS 3-D. These instruments enable the visualization of stratigraphics columns, the generation of cross sections, and the generation of 3-D models. Further information of these tools can be found in Velasco et al. (2012b) and Alcaraz (2016).

b. Hydrochemical analysis is facilitated using a set of tools QUIMET that perform quality controls, computation methods, statistical analysis and traditional graphical analysis techniques (e.g. Piper, Stiff, etc.). Further information can be found in Velasco et al. (2014)

c. Hydrogeological data analysis and interpretation is facilitated using HYYH tools, which are dedicated to query, represent, and analyse other hydrogeological data such as groundwater level, aquifer tests, and well extractions or injections. Further details can be found in Criollo et al. (2015).

All this enabled us to build a 3-D geological model following the methodological approach represented in Fig. 2. Some of these results are described in the following sections.

\section{Geological model}

The geological model presented in this paper includes the entire stratigraphic succession ranging from Paleozoic rocks at the base to recent deposits at the surface.

The Quaternary deposits unconformably overlie a heterogeneous substrate that consists of Paleozoic, Triassic, Miocene, and Pliocene rocks. In this section we first present a synthesis of the lithological and structural characteristics of the pre-Quaternary substrate (Fig. 3). Later, the Quaternary stratigraphy of the Besòs River delta is described (Figs. 4 and 5).

\subsection{Paleozoic rocks and structural evolution}

The Paleozoic substrate consists of granitic and metamorphic rocks (Fig. 3). The granitic rocks belong to the Paleozoic batholith that forms the core of the Catalan Coastal Range and the basement of the coastal shelf. They are plutonic rocks of granodioritic composition emplaced during the Carboniferous-Permian (Solé et al., 2002). During the latest stages of emplacement, a large network of porphyry dikes (locally granodioritic to granitic) and aplites, pegmatites, and porphyritic leucogranites of centimetre to metre scale intruded the granodiorites. Physico-chemical alteration of the granodiorites along joints resulted in scattered sandy material with variable amounts of clays and iron oxyhydroxides, locally referred to as the lehm. It is also often present in caliche horizons associated with major alteration zones, particularly in the low-lying areas, where the granites are more mafic.

The Paleozoic metamorphic rocks include Ordovician shales, schists, and quartzites, and Devonian limestones. They are bound in the northwest by a normal fault. Two distinct, laterally extensive series can be distinguished. These rocks were intensely folded during the Hercynian orogeny and were affected by contact metamorphism associated to the intrusion of a granitic batholith. This metamorphism that decreases with distance from the intrusion is evidenced by three primary types of metamorphic rocks: hornfels, which are pelitic in the contact zone, high-grade calc-silicate schists originated from a carbonate protolith, and schists, which represent a transition to non-metamorphosed phyllites (Sanz 


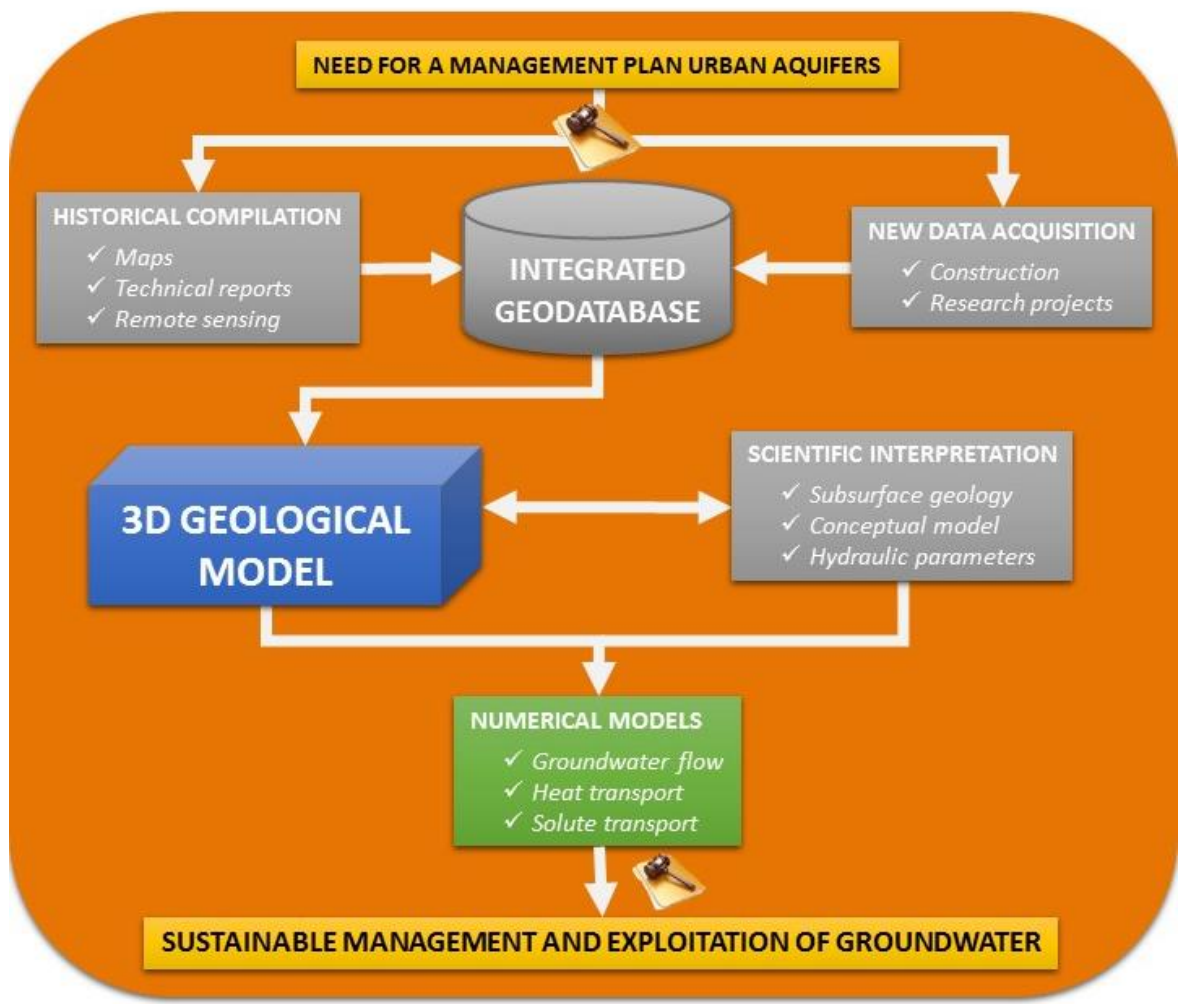

Figure 2. Outline of the methodology proposed for the efficient management of geological and hydrogeological data in an urban environment. The symbol of the folder and hammer refers to the process steps where the administration must intervene.

Parera, 1988). During the Alpine orogeny, these rocks underwent brittle fracturing that resulted in a dense network of faults. These faults separate various blocks between the Collserola range and the sea. In addition to these major faults, there are numerous joints, fractures, and local tectonic deformations. Additional evidence of intense tectonic activity is provided by the presence of mylonites in some localities.

\subsection{Triassic-Neogene units and structural evolution}

The Mesozoic rocks, specifically those of the Triassic, are limited to the hill of Montgat, which is isolated by a series of NE-SW-trending fractures (Fig. 3). These rocks consist of conglomerates interbedded with thick reddish clayey siltstones belonging to the Buntsandstein facies. There are also limestones and dolomitic limestones of the Lower Muschelkalk unit. Locally, they are positioned between two dolomitic beds, i.e. red claystones with evaporitic deposits that can be assigned to the Muschelkalk or to the Keuper. This entire sequence displays contacts that are highly fractured, which hinders accurate identification of the various rock types.

The oldest Cenozoic materials in the study area are Miocene and are restricted to the area of Badalona. They have an estimated thickness of $150 \mathrm{~m}$ and form small hills. They consist of breccias and generally massive quartzite sandstones that are reddish gray at the base and among which a complex of much less competent sandstones to claystones is sandwiched. The top of the series, which crowns the hills, consists of alternating yellow claystones, sandstones, and small conglomerate lenses. These rocks constitute another of the laterally extensive series that underlie the region and whose margins contain scattered cataclastites.

The youngest Cenozoic deposits are Pliocene and consist primarily of two distinct units. The lower unit consists of clay and blue marl of marine origin. The upper unit consists of sands and gravels with a sandy clay matrix that were derived from the coastal range. The Pliocene deposits vary greatly in thickness because their base conformed to the palaeotopography, which was controlled by staggered fault blocks extending from the mountains to the sea. These deposits are sandier toward the interior and loamier toward the coast, and were incised by numerous streams.

All these geological units constitute the substrate of the Quaternary formations. The geometry of this substrate resulted from the complex local tectonism alternating with periods of severe erosion (Fig. 3). Generally, this palaeotopography has a funnel morphology that rapidly opens to the southeast. The slope gradient is steeper near the Collserola range and gentler near the sea. The palaeotopography was affected by gully incision and by faulting. In many locations, the structure strongly controlled the drainage network development, the clearest example being the Besòs River, which 


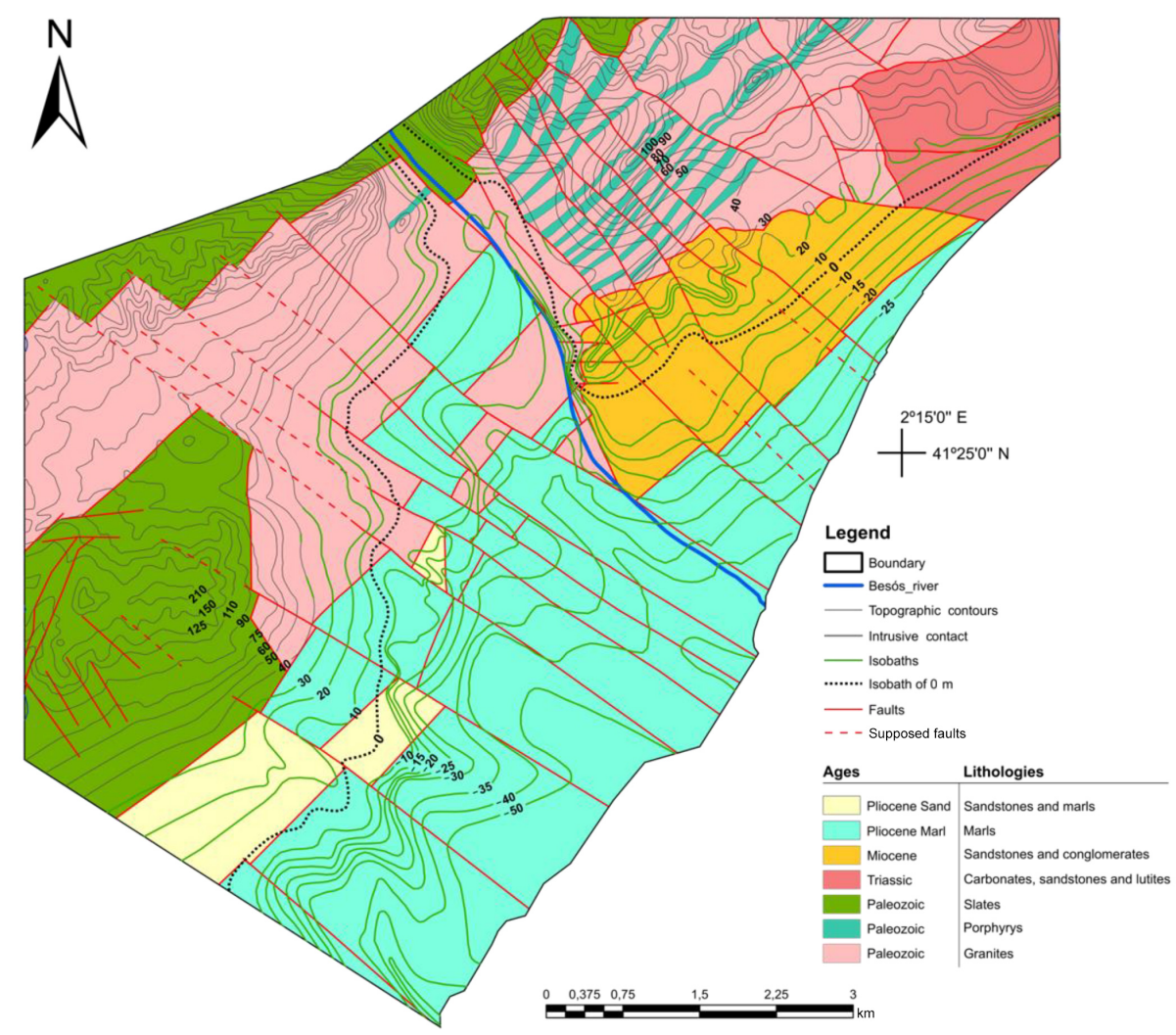

Figure 3. Geological map of the pre-Quaternary substrate of Barcelona and surroundings. This geological map was generated considering previous and additional observations performed for this work (see Sect. 3). See characteristics of the different geological units described in Sects. 4.1 and 4.2 .

largely coincides with one of the major NW-SE-trending faults. In addition, NE-SW-oriented faults also control the palaeotopography developed on the pre-Quaternary units in the form of parallel steps extending to the coast.

\subsection{Quaternary stratigraphy}

Overlying the irregular pre-Quaternary topographic surface are Quaternary formations with a maximum total thickness of $30 \mathrm{~m}$ (Figs. 4, and 5). The Pleistocene deposits consist of ancient alluvial fans. Their basal interval nearest to the Collserola range is characterized by subangular gravel in a red clay matrix. This interval grades seaward into sands and reddish clays and to red clays nearest to the sea. The Pleistocene deposits include a layer of brown and yellow eolian silt with numerous carbonate nodules (locally known as cervell de gat). A weathering profile dominated by a carbonate-rich crust (locally known as tortorà) is developed locally to a thickness of $1 \mathrm{~m}$ on the eolian silt. The alternation of these intervals is known locally as tricicle.

The Holocene deposits are the most extensive in area and consist of alluvial deposits and the Besòs River delta complex. The Holocene alluvial deposits consist of fine detrital materials (reddish clay and silt), with carbonate nodules mostly homogeneous deposited at the foot of the mountain range. It includes stream-channel gravel and sand derived from the weathering of granites from the mountain range. Alluvial deposits appear strongly modified by anthropic processes. Finally, covering much of the study area is the Besòs River delta complex.

The Besòs River delta complex is divided into two sequences with thicknesses on the order of tens of metres and bounded on the bottom and top by erosional surfaces. These surfaces represent periods of subaerial exposure probably due to Quaternary glacial-eustatic sea-level changes. The lower sequence consists primarily of distinct continental sediments and fluvial channel fill and floodplain facies. The upper sequence records deposition in various environments ranging from subaerial to marine. This sequence contains three systems tracts: a lower late lowstand systems tract, a transgressive systems tract, and an upper regressive systems tract (Velasco et al., 2012a). In total, there are six distinct stratigraphic units within the Besòs River delta complex, which are designated as units $A$ through $F$.

Unit $\mathrm{A}$ is the lowermost in the lower sequence and consists primarily of poorly sorted gravel deposited on the preQuaternary substrate. Lenticular geometries are observed in transverse sections (cross section 7 in Fig. 5), and tabular 


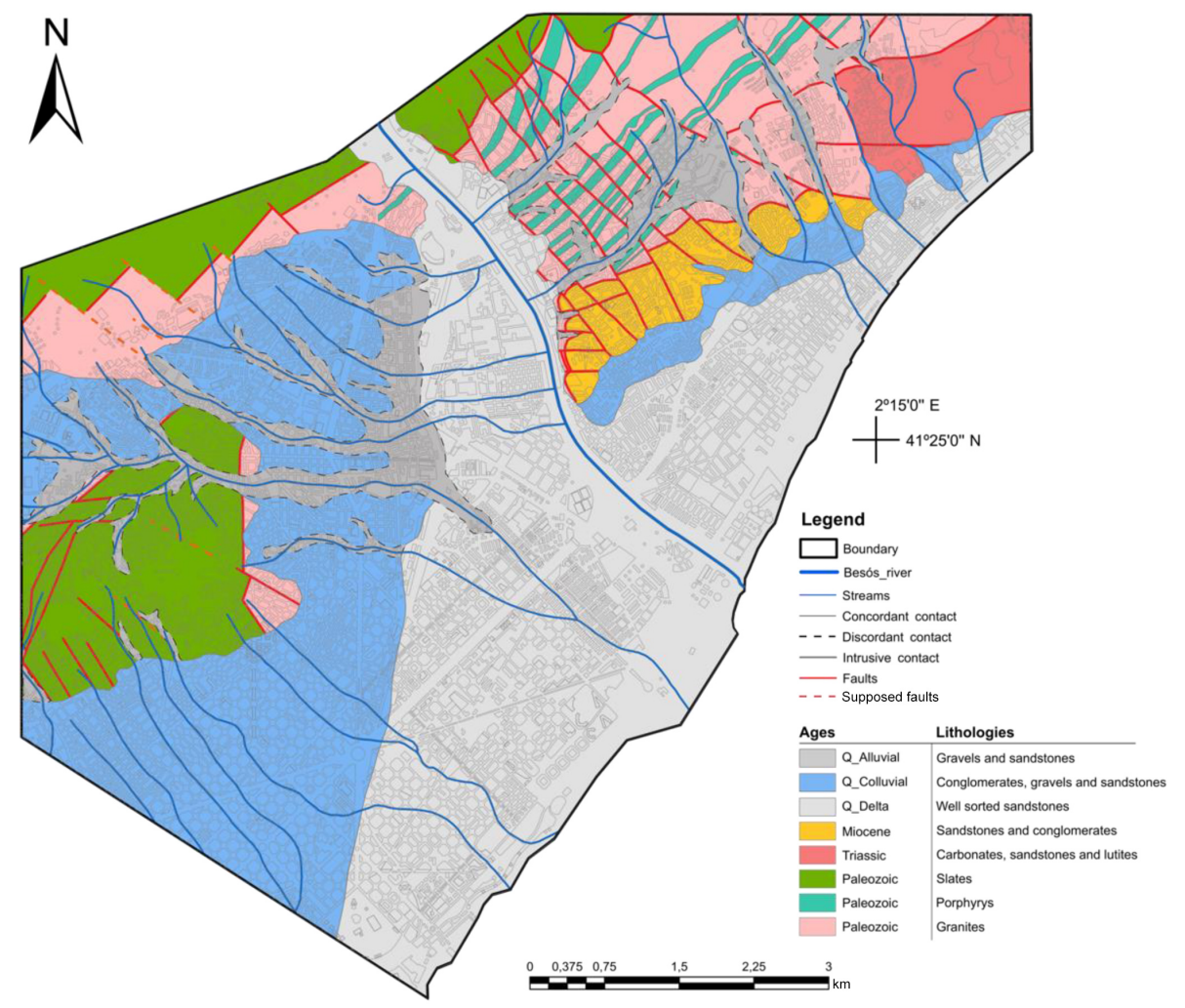

Figure 4. Geological map of Barcelona and surroundings. This geological map was generated considering previous and additional observations performed for this work (see Sect. 3). See characteristics of the different geological units described in Sects. 4.1, 4.2, and 4.3.

geometries are observed in longitudinal sections (cross section 4 in Fig. 5). The distribution of this unit is limited to the lowest areas of the palaeotopography. The origin of these deposits is linked to relative sea-level fall during the lowstand, at which time the river channels shaped the palaeotopography.

Unit B unconformably overlies unit A or the preQuaternary units and is laterally extensive. This association of facies consists primarily of gravel with mud lenses that grade laterally to muddier intervals. This unit is interpreted as a facies deposited by high-sinuosity channels during a period of relative sea-level rise and transgression.

Structurally, unit A is typically affected throughout by existing tectonic structures, whereas unit B typically represents the final stage of deformation and displays no sedimentary deformation.

Unit $\mathrm{C} 1$ unconformably overlies unit $\mathrm{B}$, unit $\mathrm{A}$, or the preQuaternary units. It consists of bodies of poorly sorted gravel that are concave upward in transverse cross sections and tabular in longitudinal sections.

Unit C2 consists of lenses of well-sorted gravel that resulted from reworking of material from unit $\mathrm{C} 1$. The contact between units $\mathrm{C} 1$ and $\mathrm{C} 2$ is interpreted as a transgressive surface, and the upper contact bounding unit $\mathrm{C} 2$ represents the maximum flooding surface.
Unit D consists of very thick beds of clay and gray silt with minor lenses of sand and contains marine fossils. Wedgeshaped geometries are observed in longitudinal sections, and lenticular geometries are observed in transverse cross sections. Based on its characteristics, this progradational unit was deposited in the pro-delta area during a sea-level rise during the highstand stage.

Similar to unit $\mathrm{D}$, unit $\mathrm{E}$ is restricted to the coastal zone. It consists of sand and gravel lenses with a certain fraction of fine material and traces of marine fossils. It corresponds to the progradational facies of the delta front.

At the top of the stratigraphic succession is unit F. It consists of lenses of sand, gravel, and mud interbedded with thick packages of mud and conglomerate. These deposits are assigned to channel-fill, overbank, and alluvial subfacies that are collectively interpreted as a proximal floodplain facies.

The youngest unit consists of localized anthropogenic fill deposits. It is heterogeneous in composition and varies widely in thickness.

\section{Discussion}

Barcelona provides a good example of sweeping changes in the management of water resources and the importance of collaboration between government and researchers for the 


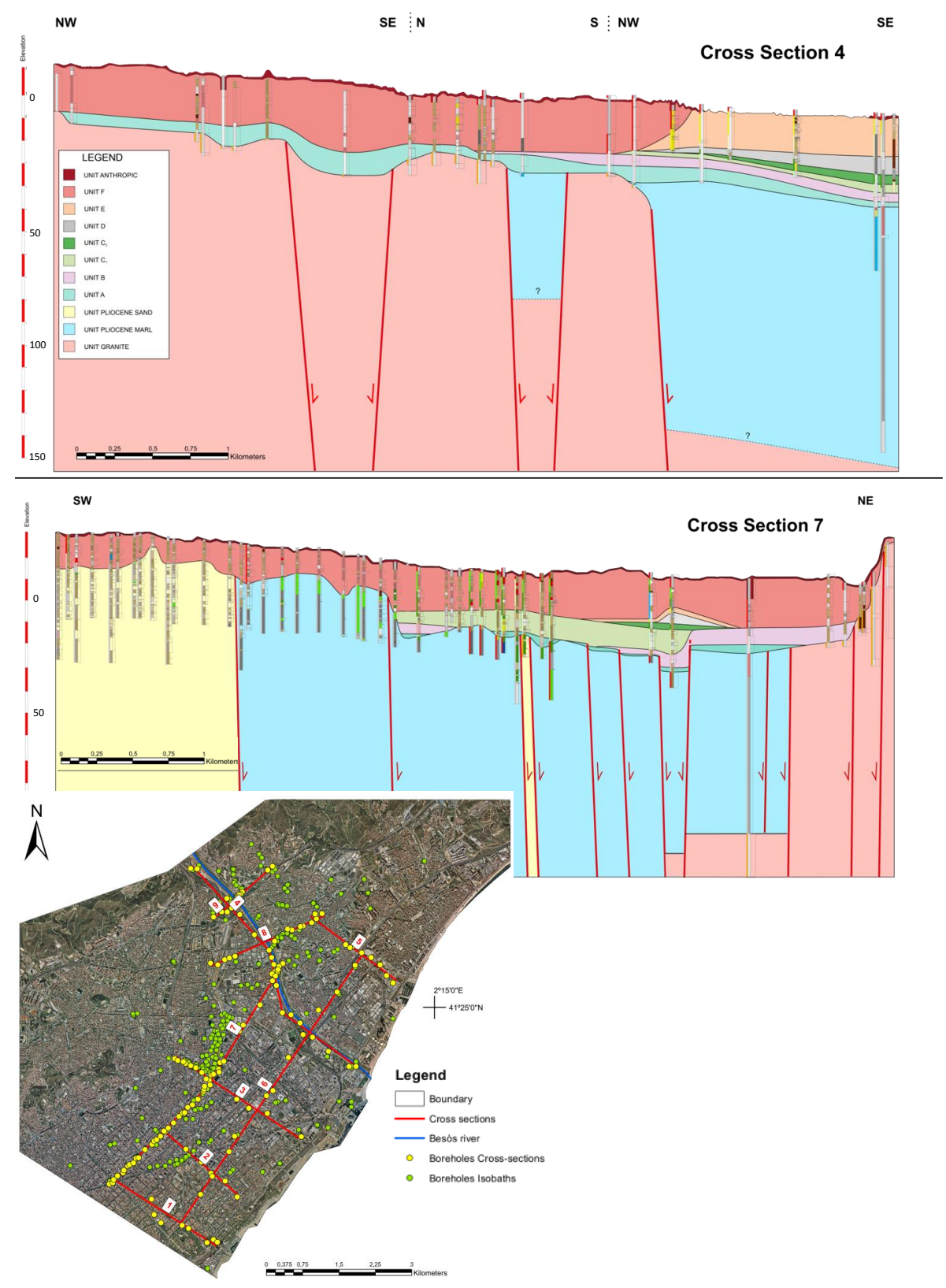

Figure 5. Sketch of geological cross sections 4 and 7. Bottom: plan view of the cross sections' position. These cross sections were performed using HEROS tools (Velasco et al., 2012a).

advancement of geological knowledge. The Hydrogeology Group (GHS) has spent many years working with the city administration on various projects, such as the project being performed with Barcelona Cicle de l'Aigua S.A. (BCASA) to create an efficient system of storing, displaying, and analysing all geohydrochemical data collected in the city.

Barcelona is located in a coastal environment, which lends it particular hydrogeological characteristics and a particular vulnerability to anthropic processes. Since the Industrial Revolution, many hydrogeological problems have affected this urban area, such as primarily fluctuations in groundwater levels, contamination of groundwater, and interactions between infrastructures and the aquifers (Vázquez-Suñé et al., 2010; Vázquez-Suñé et al., 2005).

Since the mid-nineteenth century, particularly in the twenty-first century, aquifers below the city have been heavily exploited. This sustained exploitation produced a sharp drop in groundwater levels. In some areas, the levels dropped to below sea level, which led to salinization and a loss of water quality. However, since the 1970s, an economic crisis 


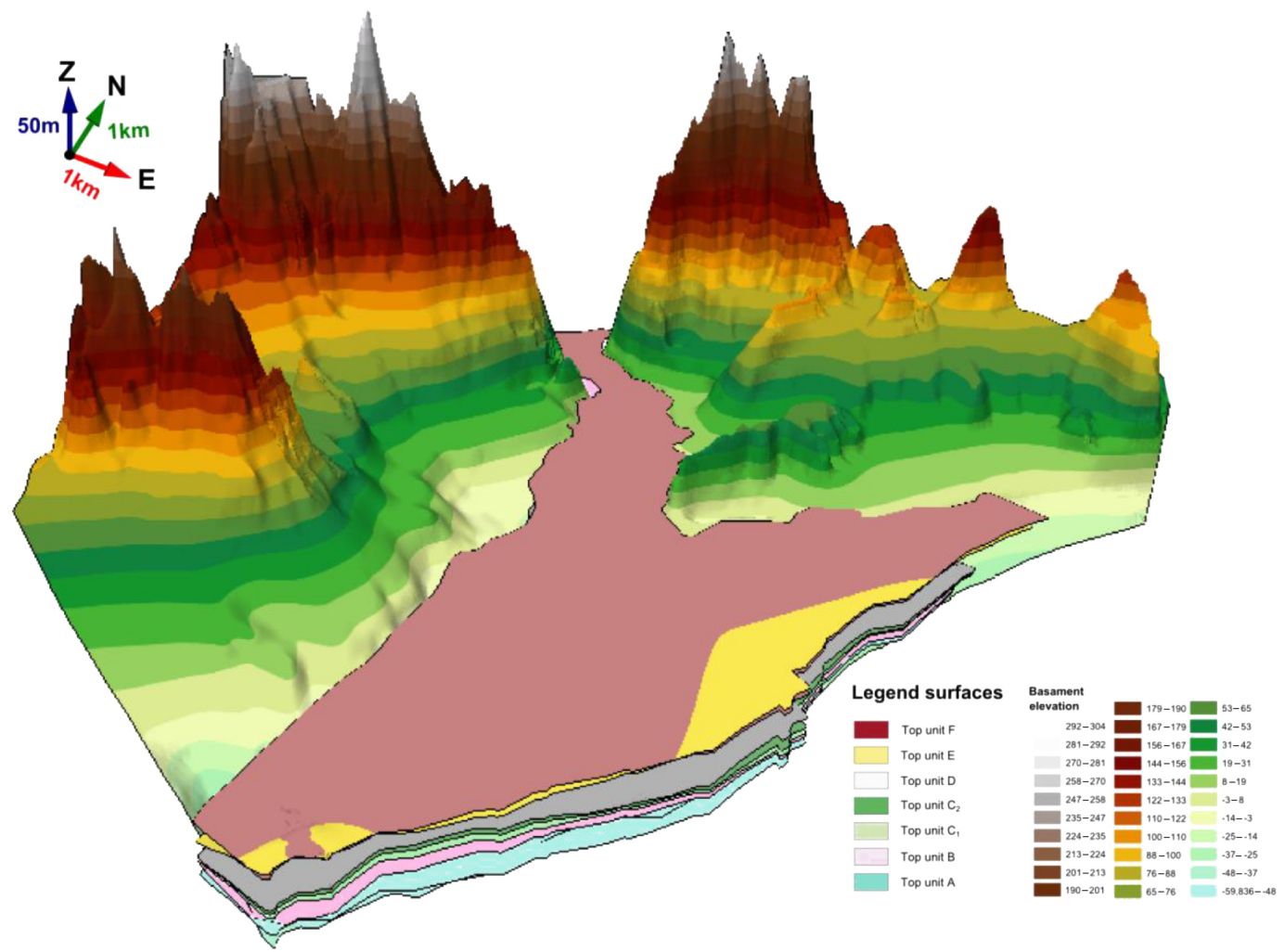

Figure 6. A 3-D model of the study area, showing the geometry of the different geological units distinguished. This model was created following the methodology proposed in this paper.

and pressure from urban residents caused the disappearance of many industries or their relocation to industrial parks on the outskirts of the city. These changes caused a decrease in groundwater extraction and a recovery of groundwater levels. This new situation led to flooding of a great deal of existing underground infrastructure (Ondiviela-Monté et al., 2005; Vázquez-Suñé et al., 2004).

Industrialization is also one of the sources of aquifer contamination in the area. A great deal of industrial waste was discharged directly into wells or was buried, thereby contaminating the soil. Today, these historical practices and discharges from the wastewater treatment plant (WWTP) and sewers are one of the main causes of groundwater contamination (Jurado et al., 2014a, b; Jurado et al., 2012b; Tubau et al., 2010).

Another major problem that the city faces is the interactions between underground infrastructures and aquifers. The dense network of underground tunnels in Barcelona (highspeed train, Metro, etc.) could create barriers to groundwater flow and cause a rise in groundwater levels upstream of the structure and a drop downstream (Font-Capó et al., 2011, 2015; Pujades et al., 2012, 2015; Culí et al., 2016). Investigations of these types of construction projects often contribute to the local body of subsurface information (Filbà et al., 2016; Font-Capó et al., 2012; Martí et al., 2008). In ad- dition, excavations in the urban environment have required special measures to decrease groundwater levels temporarily and allow for proper performance of the project (Jurado et al., 2012a; Pujades et al., 2014a, b). In recent years, there has been strong interest in developing geothermal energy (Lund and Boyd, 2016), and various projects for generating energy from groundwater are being constructed in Barcelona and Santa Coloma de Gramenet.

In recent decades, municipalities and public administrations (municipalities of Barcelona, Badalona, and Santa Coloma de Gramenet and the Catalan Water Agency (ACA)), as well as some private companies, have boosted research in this area after becoming aware of the importance of geology in groundwater management and the value of compiling and conserving relevant existing information and new information that is being generated.

For the management of groundwater in Barcelona, the Hydrogeology Group (GHS) proposes a system (Fig. 2) whose core is a standardized geodatabase containing all existing data and to which new data can be continuously added (Velasco, 2013). A set of tools developed for ArcGIS is coupled to this geodatabase and facilitates the visualization, processing, and analysis of the data. Four primary tools were developed for this purpose. HEROS was developed for analysing and interpreting geological data for the generation of 3-D ge- 
ological models. HEROS 3-D was designed to improve the 3-D visualization and modelling of 3-D surfaces. QUIMET permits the visualization and analysis of hydrogeochemical data. HYYH was developed for the analysis and interpretation of further hydrogeological data such as heads, abstractions, or aquifer tests

These efforts have resulted in an accurate 3-D model (Fig. 6) of the stratigraphy and structure beneath Barcelona. Because this model is connected to the geodatabase, which contains all available geological, hydrogeological, and geochemical data collected in the city, the data can be rapidly accessed and used at any time.

The 3-D geological model is also the basis of the numerical model of the aquifer behaviour and the basis for developing an action plan for sustainable exploitation of the groundwater and its energy resources. Two examples of this process at work in the management of geothermal resources in the vicinity of Barcelona are the studies by Alcaraz et al. (2016) and García-Gil et al. (2015a).

As a result, quality geological information can be obtained in an urban environment, where exposures are scarce and geophysical surveys are difficult to perform. From an administrative standpoint, this thorough knowledge of the geology of the city acquired by researchers yields a 3-D geological model that, coupled with GIS tools developed by the research group, will allow for effective management of the groundwater and energy resources below Barcelona. The administration and private companies then feedback information that contributes to further research.

\section{Conclusions}

This study shows the need for a symbiotic relationship between government and research groups for efficient management of geological data in urban environments. The strategy for achieving this goal requires that government agencies first make existing geological, geotechnical, and hydrologic data available and those tools are then developed to manage the existing data and any new data that are acquired. This strategy is being applied in Barcelona, where a standardized geodatabase has been developed to manage the available data and incorporate new data rapidly and efficiently. We have developed a set of tools within a GIS environment that facilitate the representation and processing of 3-D data. By connecting the 3-D geological model with the geodatabase, it is possible to start with a 3-D model and create a powerful tool for managing aquifers and their interactions with construction projects. Thus, despite the difficulty of investigating the subsurface in an urban environment, a highly detailed geological model has been made available.

Finally, through its implementation, both the city administration and private companies benefit from the feedback of geological knowledge acquired during this process, thereby substantially reducing the cost of construction projects and facilitating the development of aquifer management plans.

Acknowledgements. This paper is dedicated to the memory of Andrés Pérez-Estaún, whose friendship, skill, and dedication were essential to this work, but also for his continuous support, discussion, and encouragement in the study of Barcelona geology. The authors wish to acknowledge funding by the Spanish Ministry of Economy and Competitiveness projects: MEPONE (BIA201020244) and MEDISTRAES (CGL2013-48869-C2-1-R), and by the Generalitat de Catalunya (Grup Consolidat de Recerca: Grup d'Hidrologia Subterrània, 2009-SGR-1057). We would also like to acknowledge ADIF, GISA, DPTOP Generalitat de Catalunya (Infrastructure administration), Ajuntament de Barcelona, Ajuntament de Sant Adrià del Besòs, Ajuntament de Badalona, Ajuntament de Santa Coloma de Gramenet, BCASA, BR Urban Development Agency, AMB Metropolitan Area of Barcelona (Local administrations), Catalan Water Agency (ACA), and several companies such as UTELinia9, SACYR, ACCIONA, OHL, GEOCONSULT, FCC, Ferrovial-Agroman, INTECSA-INARSA, COPISA, COPCISA, among others, for their help in providing technical documents and data used for this study, and also, for their support throughout the hydrogeological monitoring and assessment of different civil works.

Edited by: F. Bastida

Reviewed by: two anonymous referees

\section{References}

Aeschbach-Hertig, W. and Gleeson, T.: Regional strategies for the accelerating global problem of groundwater depletion, Nat. Geosci., 5, 853-861, 2012.

Alcaraz, M., Garcia-Gil, A., Vazquez-Sune, E., and Velasco, V.: Advection and dispersion heat transport mechanisms in the quantification of shallow geothermal resources and associated environmental impacts, Sci. Total. Environ., 543, 536-546, 2016.

Almera, J.: Descripción de los terrenos pliocénicos de la cuenca del Bajo Llobregat y llano de Barcelona, in: Mapa Geol. Prov., Barcelona, 1894.

Attard, G., Winiarski, T., Rossier, Y., and Eisenlohr, L.: Review: Impact of underground structures on the flow of urban groundwater, Hydrogeol. J., 24, 5-19, 2015.

Banda, E. and Santanach, P.: The Valencia trough (western Mediterranean): An overview, Tectonophysics, 208, 183-202, 1992.

Carlson, M. A., Lohse, K. A., McIntosh, J. C., and McLain, J. E. T.: Impacts of urbanization on groundwater quality and recharge in a semi-arid alluvial basin, J. Hydrol., 409, 196-211, 2011.

Criollo, R., Velasco, V., Vázquez-Suñé, E., Serrano-Juan, A., Alcaraz, M., and García-Gil, A.: An integrated GIS-based tool for Aquifer Test Analysis, Environ. Earth Sci., 75, doi:10.1007/s12665-016-5292-3, 2015.

Culí, L., Pujades, E., Vazquez-Suñe, E., and Jurado, A.: Modelling of the EPB TBM shield tunnelling advance as a tool for geological characterization, Tunn. Undergr. Sp. Tech., 56, 12-21, doi:10.1016/j.tust.2016.02.017, 2016.

Culshaw, M. G. and Price, S. J.: The contribution of urban geology to the development, regeneration and conservation of cities, 
Bull. Eng. Geol. Environ., 70, 333-376, doi:10.1007/s10064011-0377-4, 2011.

Davies, T. C.: Urban geology of African megacities, J. Afr. Earth Sci., 110, 188-226, 2015.

de Rienzo, F., Oreste, P., and Pelizza, S.: Subsurface geologicalgeotechnical modelling to sustain underground civil planning, Eng. Geol., 96, 187-204, 2008.

Di Salvo, C., Di Luzio, E., Mancini, M., Moscatelli, M., Capelli, G., Cavinato, G. P., and Mazza, R.: GIS-based hydrostratigraphic modeling of the city of Rome (Italy): analysis of the geometric relationships between a buried aquifer in the Tiber Valley and the confining hydrostratigraphic complexes, Hydrogeol. J., 20, 1549-1567, 2012.

Epting, J., Händel, F., and Huggenberger, P.: Thermal management of an unconsolidated shallow urban groundwater body, Hydrol. Earth Syst. Sci., 17, 1851-1869, doi:10.5194/hess-17-18512013, 2013.

Ferguson, G.: Subsurface heat flow in an urban environment, J. Geophys. Res., 109, B02402, doi:10.1029/2003JB002715, 2004.

Ferguson, G. and Woodbury, A. D.: Urban heat island in the subsurface, Geophys. Res. Lett., 34, L23713, doi:10.1029/2007GL032324, 2007.

Filbà, M., Salvany, J. M., Jubany, J., and Carrasco, L.: Tunnel boring machine collision with an ancient boulder beach during the excavation of the Barcelona city subway L10 line: A case of adverse geology and resulting engineering solutions, Eng. Geol., 200, 31-46, 2016.

Font-Capó, J., Vázquez-Suñé, E., Carrera, J., Martí, D., Carbonell, R., and Pérez-Estaun, A.: Groundwater inflow prediction in urban tunneling with a tunnel boring machine (TBM), Eng. Geol., 121, 46-54, 2011.

Font-Capó, J., Vazquez-Sune, E., Carrera, J., and Carbonell, R.: Groundwater characterization of a heterogeneous granitic rock massif for shallow tunneling, Geol. Acta, 10, 395-408, 2012.

Font-Capó, J., Pujades, E., Vàzquez-Suñé, E., Carrera, J., Velasco, V., and Montfort, D.: Assessment of the barrier effect caused by underground constructions on porous aquifers with low hydraulic gradient: A case study of the metro construction in Barcelona, Spain, Eng. Geol., 196, 238-250, 2015.

Gámez, D., Simó, J. A., Lobo, F. J., Barnolas, A., Carrera, J., and Vázquez-Suñé, E.: Onshore-offshore correlation of the Llobregat deltaic system, Spain: Development of deltaic geometries under different relative sea-level and growth fault influences, Sediment. Geol., 217, 65-84, 2009.

García-Faria, P.: Plano detallado de la urbanización de Barcelona y su alcantarillado, esc. $1: 5000$, http://www.anycerda.org/web/ es/arxiu-cerda/fitxa/projecte-de-sanejament/362 (last access: 5 September 2016), 1891.

García-Gil, A., Vázquez-Suñe, E., Alcaraz, M. M., Juan, A. S., Sánchez-Navarro, J. Á., Montlleó, M., Rodríguez, G., and Lao, J.: GIS-supported mapping of low-temperature geothermal potential taking groundwater flow into account, Renew. Energ., 77, 268-278, 2015a.

García-Gil, A., Vázquez-Suñé, E., Sánchez-Navarro, J. Á., and Mateo Lázaro, J.: Recovery of energetically overexploited urban aquifers using surface water, J. Hydrol., 531, 602-611, 2015b.

García-Gil, A., Vázquez-Suñe, E., Schneider, E. G., SánchezNavarro, J. Á., and Mateo-Lázaro, J.: Relaxation factor for geothermal use development - Criteria for a more fair and sus- tainable geothermal use of shallow energy resources, Geothermics, 56, 128-137, 2015c.

Gaspar-Escribano, J. M., Garcia-Castellanos, D., Roca, E., and Cloetingh, S.: Cenozoic vertical motions of the Catalan Coastal Ranges (NE Spain): The role of tectonics, isostasy, and surface transport, Tectonics, 23, TC1004, doi:10.1029/2003TC001511, 2004.

Gleeson, T., Alley, W. M., Allen, D. M., Sophocleous, M. A., Zhou, Y., Taniguchi, M., and VanderSteen, J.: Towards sustainable groundwater use: setting long-term goals, backcasting, and managing adaptively, Ground Water, 50, 19-26, 2012a.

Gleeson, T., Wada, Y., Bierkens, M. F., and van Beek, L. P.: Water balance of global aquifers revealed by groundwater footprint, Nature, 488, 197-200, 2012b.

Gleeson, T., Befus, K. M., Jasechko, S., Luijendijk, E., and Cardenas, M. B.: The global volume and distribution of modern groundwater, Nat. Geosci., 9, 161-167, 2015.

Grimm, N. B., Faeth, S. H., Golubiewski, N. E., Redman, C. L., Wu, J., Bai, X., and Briggs, J. M.: Global change and the ecology of cities, Science, 319, 756-760, 2008.

Huggenberger, P. and Epting, J.: Urban Geology: Process-Oriented Concepts for Adaptative and Integrated Resource Management, Springer, 2011.

Huggenberger, P., Epting, J., and Scheidler, S.: Concepts for the sustainable management of multi-scale flow systems: the groundwater system within the Laufen Basin, Switzerland, Environ. Earth Sci., 69, 645-661, 2013.

Instituto Geológico y Minero de España (IGME): Mapa Geológico de España, Map number 421, Scale 1:50,000, Instituto Geológico y Minero de España, 1977.

Institut Geològic de Catalunya-Instituto Geológico y Minero de Españal (IGC-IGME): Mapa geològic comarcal de Catalunya, Map number 13. Barcelonès, Scale $1: 50,000$, Institut Geològic de Catalunya-Instituto Geológico y Minero de España (IGCIGME), 2005.

Jurado, A., De Gaspari, F., Vilarrasa, V., Bolster, D., Sánchez-Vila, X., Fernàndez-Garcia, D., and Tartakovsky, D. M.: Probabilistic analysis of groundwater-related risks at subsurface excavation sites, Eng. Geol., 125, 35-44, 2012a.

Jurado, A., Mastroianni, N., Vazquez-Sune, E., Carrera, J., Tubau, I., Pujades, E., Postigo, C., de Alda, M. L., and Barcelo, D. Drugs of abuse in urban groundwater. A case study: Barcelona, Sci. Total Environ., 424, 280-288, 2012b.

Jurado, A., Gago-Ferrero, P., Vazquez-Sune, E., Carrera, J., Pujades, E., Diaz-Cruz, M. S., and Barcelo, D.: Urban groundwater contamination by residues of UV filters, J. Hazard. Mater., 271, 141-149, 2014a.

Jurado, A., Lopez-Serna, R., Vazquez-Sune, E., Carrera, J., Pujades, E., Petrovic, M., and Barcelo, D.: Occurrence of carbamazepine and five metabolites in an urban aquifer, Chemosphere, 115, 4753, 2014b.

Kazemi, G. A.: Impacts of urbanization on the groundwater resources in Shahrood, Northeastern Iran: Comparison with other Iranian and Asian cities, Phys. Chem. Earth, Parts A/B/C, 36, 150-159, 2011.

Lewis, C. J., Vergés, J., and Marzo, M.: High mountains in a zone of extended crust: Insights into the Neogene-Quaternary topographic development of northeastern Iberia, Tectonics, 19, 86$102,2000$. 
Llobet-Vall-llosera, J. A.: Acerca de la descripción jeognóstica del terreno que ocupa la ciudad de Barcelona, Bol. R. Ac. Cienc. Nat. y Artes de Barcelona, 4, 2-7, 1840.

Lund, J. W. and Boyd, T. L.: Direct utilization of geothermal energy 2015 worldwide review, Geothermics, 60, 66-93, 2016.

Martí, D., Carbonell, R., Flecha, I. Palomeras, I., Font-Capó, J., Vázquez-Suñé, E., and Pérez-Estaún, A.: "High-resolution seismic characterization in an urban area: Subway tunnel construction in Barcelona, Spain", Geophysics, 73, B41-B50, doi:10.1190/1.2832626, 2008.

McDonald, R. I., Weber, K., Padowski, J., Flörke, M., Schneider, C., Green, P. A., Gleeson, T., Eckman, S., Lehner, B., Balk, D., Boucher, T., Grill, G., and Montgomery, M.: Water on an urban planet: Urbanization and the reach of urban water infrastructure, Global Environ. Change, 27, 96-105, 2014.

Menberg, K., Bayer, P., Zosseder, K., Rumohr, S., and Blum, P.: Subsurface urban heat islands in German cities, Sci. Total Environ., 442, 123-133, 2013.

Moracas, G.: Estudio general régimen aguas contenidas en terrenos permeables régimen corriente subterránea delta río Besòs, Rev. Obras Públicas, 1896, 1-133, 1896.

Ondiviela-Monté, M., Vázquez-Suñé, E., Nilsson, J., Carrera, J., Sánchez-Vila, X., and Casas, J.: Groundwater Intensive Use, in: Groundwater Intensive Use, edited by: Sahuquillo, A., Capilla, J., Martínez-Cortina, L., and Sánchez-Vila, X., International Association of Hydrogeologists Selected Papers, 2005.

Parriaux, A., Tacher, L., and Joliquin, P.: The hidden side of cities towards three-dimensional land planning, Energ. Buildings, 36, 335-341, 2004.

Pujades, E., López, A., Carrera, J., Vázquez-Suñé, E., and Jurado, A.: Barrier effect of underground structures on aquifers, Eng. Geol., 145-146, 41-49, 2012.

Pujades, E., Vàzquez-Suñé, E., Carrera, J., and Jurado, A.: Dewatering of a deep excavation undertaken in a layered soil, Eng. Geol., 178, 15-27, 2014a.

Pujades, E., Vázquez-Suñé, E., Carrera, J., Vilarrasa, V., De Simone, S., Jurado, A., Ledesma, A., Ramos, G., and Lloret, A.: Deep enclosures versus pumping to reduce settlements during shaft excavations, Eng. Geol., 169, 100-111, 2014b.

Pujades, E., Vázquez-Suñé, E., Culí, L., Carrera, J., Ledesma, A., and Jurado, A.: Hydrogeological impact assessment by tunnelling at sites of high sensitivity, Eng. Geol., 193, 421-434, 2015.

Riba, O. and Colombo, F.: Barcelona: La Ciutat Vella i el Poblenou. Assaig de geologia urbana, Institut d'Estudis Catalans and Reial Acadèmia de Ciències i Arts de Barcelona, 278 pp., Barcelona, 2009.

Roca, E. and Guimerà, J.: The Neogene structure of the eastern Iberian margin: structural constraints on the crustal evolution of the Valencia trough (wetern Mediterranean), Tectonophysics, 203, 203-218, 1992.

Roca, E., Sans, M., Cabrera, L., and Marzo, M.: Oligocene to Middle Miocene evolution of the central Catalan margin (northwestern Mediterranean), Tectonophysics, 315, 209-233, 1999.

Rubio, C. and Kindelan, A.: Apuntes para el estudio de la hidrología subterránea del llano de Barcelona, Bol. Comisión. Mapa Geol. Esp., 30, 93-102, 1909.
Salvany, J. M.: Análisis y correlación de sondeos mecánicos en los depósitos miocenos de Montjuïc (Barcelona): implicaciones estructurales, Estudios Geológicos, 69, 149-171, 2013.

Santanach, P., Casas, J. M., Gratarcos, O., Liesa, M., and Sàbat, F.: Variscan and Alpine structure of the hills of Barcelona: geology in an urban area, J. Iber. Geol., 37, 121-136, 2011.

Sanz Parera, M.: El Pla de Barcelona: Constitució i característiques físiques, Els llibres de la frontera, 1988.

Solé, J., Cosca, M., Sharp, Z., and Enrique, P.: 40 Ar/39 Ar Geochronology and stable isotope geochemistry of LateHercynian intrusions from north-eastern Iberia with implications for argon loss in K-feldspar, Int. J. Earth Sci., 91, 865-881, 2002.

Solé-Sabarís, L.: Ensayo de itnerpretación del Cuaternario Barcelonés, Miscel. Barcilonensia, 1963.

Taniguchi, M., Burnett, W. C., and Ness, G. D.: Integrated research on subsurface environments in Asian urban areas, Sci. Total. Environ., 404, 377-392, 2008.

Tessler, Z. D., Vörösmarty, C. J., Grossberg, M., Gladkova, M., Aizenman, H., Syvitski, J. P. M., and Foufoula-Georgiou, E.: Profiling risk and sustainability in coastal deltas of the world, Science, 349, 638-643, 2015.

Tubau, I., Vázquez-Suñé, E., Carrera, J., González, S., Petrovic, M., López de Alda, M. J., and Barceló, D.: Occurrence and fate of alkylphenol polyethoxylate degradation products and linear alkylbenzene sulfonate surfactants in urban ground water: Barcelona case study, J. Hydrol., 383, 102-110, 2010.

Vázquez-Suñé, E., Sánchez-Vila, X., Carrera, J., and Arandes, R.: ¿La explotación intensiva puede ser beneficiosa? Efectos del cese de la explotación intensiva en la ciudad de Barcelona. In: El agua y la ciudad sostenible: Hidrogeología urbana, AIH-GE, IGME ed. ISBN: 84-7840-539-9, Madrid, 73-82, 2004.

Vázquez-Suñé, E., Sánchez-Vila, X., and Carrera, J.: Introductory review of specific factors influencing urban groundwater, an emerging branch of hydrogeology, with reference to Barcelona, Spain, Hydrogeol. J., 13, 522-533, 2005.

Vázquez-Suñé, E., Abarca, E., Carrera, J., Capino, B., Gámez, D., Pool, M., Simó, T., Batlle, F., Niñerola, J. M., and Ibáñez, X.: Groundwater modelling as a tool for the European Water Framework Directive (WFD) application: The Llobregat case, Phys. Chem. Earth, Parts A/B/C, 31, 1015-1029, 2006.

Vázquez-Suñé, E., Carrera, J., Tubau, I., Sánchez-Vila, X., and Soler, A.: An approach to identify urban groundwater recharge, Hydrol. Earth Syst. Sci., 14, 2085-2097, doi:10.5194/hess-142085-2010, 2010.

Velasco, V.: GIS-based hydrogeological platform for sedimentary media, $\mathrm{PhD}$ Thesis, Universidad Politécnica de Cataluña (UPC), 158 pp., Barcelona, http://www.tesisenred.net/handle/ 10803/135005 (last access: September 2016), 2013.

Velasco, V., Cabello, P., Vázquez-Suñé, E., López-Blanco, M., Ramos, E., and Tubau, I.: A sequence stratigraphic based geological modelin the urbanized area of the Quaternary Besòs delta (NW Mediterranean coast, Spain), Geol. Acta, 10, 373393, 2012a.

Velasco, V., Gogu, R., Vázquez-Suñè, E., Garriga, A., Ramos, E., Riera, J., and Alcaraz, M.: The use of GIS-based 3D geological tools to improve hydrogeological models of sedimentary media in an urban environment, Environ. Earth Sci., 68, 2145-2162, 2012 b. 
Velasco, V., Tubau, I., Vázquez-Suñè, E., Gogu, R., Gaitanaru, D., Alcaraz, M., Serrano-Juan, A., Fernàndez-Garcia, D., Garrido, T., Fraile, J., and Sanchez-Vila, X.: GIS-based hydrogeochemical analysis tools (QUIMET), Comput. Geosci., 70, 164-180, 2014.

Ventayol, A.: Mapa Geològic de Barcelona, http://www. boschiventayol.com/es/mapa/, last access: March 2016.

Ventayol, A., Albaigés, A., Cortal, J. M., Gallart, F., López, C., López, J. L., and Santaeularia, J.: Mapa geotécnico de Barcelona, Esplugues, l'Hospitalet, Sant Adrià, Santa Coloma, 1978.

Vörösmarty, C. J., Green, P. A., Salisbury, J., and Lammers, R. B.: Global Water Resources: Vulnerability from Climate Change and Population Growth, Science, 289, 284-288, 2000.
WFD: Directive 2000/60/EC of the European Parliament and of the Council of 23 October 2000 establishing a framework for Community action in the field of water policy, 2000.

Zhou, W., Minnick, M. D., Mattson, E. D., Geza, M., and Murray, K. E.: GIS-based geospatial infrastructure of water resource assessment for supporting oil shale development in Piceance Basin of Northwestern Colorado, Comput. Geosci., 77, 44-53, 2015. 